\title{
Psicologia jurídica: implicações conceituais e aplicações práticas
}

\author{
Murilo Angeli Dias dos Santos*
}

Caires, M. A. F. (2003). Psicologia jurídica: implicações conceituais e aplicações práticas. São Paulo: Vetor, 205 p.

A psicologia jurídica é especialidade pouco estudada e pesquisada, apesar de sua importância e utilização pelo Direito, sobretudo no âmbito criminal, mas também no âmbito cível, trabalhista e até administrativo. Com isso, a dificuldade encontrada pelo psicólogo ao emitir seu laudo ou parecer a pedido do Poder Judiciário é assaz evidente. Diante dessa constatação, a autora objetivou em sua pesquisa ampliar a discussão sobre o assunto, visando a uma maior sistematização da matéria de tão relevante valor social.

O livro, subdividido em cinco capítulos, resultou da dissertação de mestrado da autora que, a partir de seu aceite para integrar a Unidade de Psicologia do Instituto de Medicina Social e Criminologia de São Paulo (IMESC), constatou a preocupante escassez doutrinária na área. Com sua pesquisa, Maria Adelaide de Freitas Caires eleva a psicologia jurídica ao patamar de disciplina distinta e diferenciada em relação à psicologia clínica, embora reconheça os aspectos que as mantêm correlatas.

O capítulo inicial traz uma contextualização da psicologia jurídica e suas disciplinas afins pela história e traça um panorama da prática pericial que aponta para sua origem na Antigüidade, época em que, sobretudo por meio da medicina legal, começou a ser abraçada pelas mais diversas legislações. Mostra também o percurso histórico da perícia no Brasil, país que, somente por volta de quatrocentos anos após seu descobrimento, iniciou alguns estudos médico-legais com maior independência em relação à orientação científico-doutrinária portuguesa. No tocante à psicologia propriamente dita, a autora afirma que se desvinculou da filosofia somente em meados do séc. XIX, inicialmente compondo apenas o corpo doutrinário das ciências médicas. Ainda nesse capítulo, contextualiza o Direito no mundo e no Brasil, tecendo breves - mas imprescindíveis para o público ao qual o livro se destina - explicações acerca do que chama "universo judicial".

Ao final do capítulo, a autora define o campo de atuação da psicologia jurídica que, conforme o momento e a forma de atuação no processo legal, pode ser subdividida em psicologia forense e criminal. Esclarece também que a perícia não se reduz a mero meio de prova, pois tem como função instruir e subsidiar tecnicamente as teses das partes e sentenças dos juízes. Há necessidade da atuação da psicologia jurídica sempre quando aspectos psíquicos ou psicológicos forem suscitados ou como fatos jurídicos ou como fatores de extinção, modificação ou constituição da convicção acerca da conduta sub judice.

O segundo capítulo trata do método utilizado para responder aos questionamentos sobre a possibilidade de organização da psicologia jurídica como área de conhecimento específico e de atuação especializada. A análise documental e o estudo de caso foram os métodos eleitos, visando à exposição das aplicações práticas e das implicações teóricas da pesquisa.

No terceiro capítulo, além da descrição dos casos estudados, a autora apresenta os questionamentos e as reflexões sobre a prática em psicodiagnóstico para fins judiciais. Assevera que a simples aplicação do método clínico para a elaboração do laudo ou parecer como resposta aos questionamentos judiciais pode tanto propiciar sentenças errôneas por parte dos magistrados - em razão da compreensão insuficiente ou equivocada como colocar em descrédito a importância do trabalho do psicólogo no universo jurídico. Apesar da técnica e dos conhecimentos clínicos serem imprescindíveis à sua prática, algumas peculiaridades da psicologia jurídica a tornam uma disciplina autônoma em relação à psicologia clínica em vários aspectos. Dentre eles, é destacada a especificidade dos fatores de alteração de comportamento analisados, pois ultrapassam o âmbito da saúde e atingem a sociedade como um todo, tanto que exigem a intervenção da lei. Outro aspecto diferenciador é o do relacionamento psicólogo-paciente, pois não é o indivíduo quem procura o psicólogo, o atendimento é obrigatório. Com isso, a autora propõe repensar os procedimentos clínicos a fim de ordená-los e dirigi-los de modo que se adaptem às situações peculiares encontradas, às características do examinado e ao fim ao qual se destina o exame, sempre tendo em vista que sua exposição deve se ater apenas aos elementos estritamente necessários ao deslinde das questões judiciais.

No quarto capítulo, é apresentada a discussão dos resultados e a reflexão sobre as particularidades encontradas na prática psicológica pericial. Ele destaca duas características fundamentais: a primeira, a ausência da queixa clínica, havendo apenas dúvidas do magistrado, e a segunda, o fato do objeto de estudo envolver não só

\footnotetext{
* Endereço para correspondência:

E-mail: santosm@universia.com.br
} 
questões jurídico-psicológicas como também questões sociais. Trata-se de uma parceria psicologia-direito que partilha os componentes psicológicos (cognitivos, intelectuais e de personalidade); os sociais (capacidade de adesão às normas e aos limites sociais, capacidade de adaptação social, grupo étnico, grupo social e fatores de risco); e os jurídicos (grau de periculosidade, grau de responsabilidade e enquadramento em programas reeducativos). É uma área que extrapola até mesmo os horizontes da ciência psicológica ao incorporar tais componentes sociais e jurídicos ao caso específico. O capítulo traz ainda a subdivisão da psicologia jurídica, conforme sua área de atuação. Cabem, por um lado, à denominada psicologia forense, as elucidações necessárias ao transcorrer do processo, seja no âmbito penal, civil ou trabalhista. Por outro lado, a atuação da psicologia criminal ocorre na fase de execução da pena, após a tramitação do processo penal e da sentença condenatória, cabendo ao psicólogo realizar o psicodiagnóstico em detentos, com vistas à progressão da pena ou à sua conversão em medidas substitutivas.

O livro é finalizado com as Consideracões finais e conclusões, momento em que a autora reafirma a psicologia jurídica como disciplina distinta, mas não totalmente independente da atividade clínica, por não prescindir completamente dela. Suas necessidades e objetivos particulares repousam, sobretudo, na construção da convicção jurídica e em propiciar a utilização do remédio jurídico mais pertinente.

A obra apresenta uma crítica sobre as circunstâncias da cultura jurídica como o linguajar erudito dos códigos, que define como inacessível para grande parcela da população. Apesar desta inegável realidade, a autora vai mais além, apresentando no transcorrer do livro uma concepção meramente sociológica do direito na medida em que reduz a ordem jurídica à sociologia, afirmando a última como fonte, método e conteúdo da primeira.

De forma geral, a obra contribui para uma área pouco explorada e carente de pesquisas, traz informações relevantes sobre os meandros da relação entre a Psicologia e o Direito, o que permite - e talvez requeira - que seja estudada de maneira multidisciplinar. O livro oferece uma abordagem diferenciada para o psicodiagnóstico jurídico e mostra a necessidade de uma análise prévia dos autos do processo e a elaboração de um estudo psicossocial das peças como momentos antecedentes e fundamentais à elaboração do laudo ou parecer. Mesmo não tendo o propósito de desenvolver um modelo para a prática da psicologia jurídica, a obra fornece subsídios e motivos suficientes para um desenvolvimento específico e diferenciado dessa disciplina. Tudo isso a faz indicada para estudantes e profissionais tanto da Psicologia como do Direito.

\section{Sobre o autor:}

Murilo Angeli Dias dos Santos é advogado formado pela USF, graduando da Faculdade de Filosofia da PUCCampinas e mestrando do Programa de Pós-Graduação em Filosofia da Universidade São Judas Tadeu. 